Dorota Grabowska*

Toruń

\title{
Prawda i uczciwość w sferze publicznej, Colloquia Torunensia XIX Toruń, 8-9 listopada 2013 roku
}

W dniach 8-9 listopada 2013 roku odbyły się w XIX Toruńskie Spotkania Colloquia Torunensia. Podczas tych dwudniowych obrad nad Prawdą i uczciwością w sferze publicznej dyskutowali filozofowie, etycy, socjologowie, duchowni, przedstawiciele samorządu oraz świata mediów. Pierwszego dnia, 8 listopada 2013 roku, rozmowny toczyły się w węższym gronie specjalistów w Centrum Dialogu im. bł. Jana Pawła II w Toruniu. Podczas dyskusji panelowej zaproszeni uczestnicy-eksperci usystematyzowali pojęcia i płaszczyzny polemik, a także zaprezentowali najważniejsze zagadnienia związane z tematem tegorocznych rozważań, czyli prawdy i uczciwości w sferze publicznej. Spotkanie moderował prof. Ryszard Wiśniewski, etyk z UMK. W pierwszej części piątkowych obrad wystapił prof. Krzysztof Stachewicz. Mówił on o związku językowym i etycznym oraz aksjologicznych uwarunkowaniach obu wojen. Następnie ks. prof. Mirosław Mróz nakreślił biblijne źródła oraz wyjaśnił sens przykazania „Nie mów fałszywego świadectwa przeciw bliźniemu swemu!” Tematykę dotyczącą filozofii dialogu, ze szczególnym zwróceniem uwagi na prawdę i uczciwość jako fundamentalne wartości w życiu człowieka, zaprezentował dr Piotr Domeracki. Podkreślił, że prawda należy do człowieka, jest mu pomocna, ale nie należy się każdemu, lecz tylko temu, kto ją potrafi kompetentnie przekazać.

* Mgr Dorota Grabowska jest absolwentką historii i pedagogiki, doktorantką na Wydziale Nauk Pedagogicznych Uniwersytetu Mikołaja Kopernika w Toruniu. 
Druga część piątkowych obrad miała wymiar bardziej praktyczny. W tym kontekście głos zabrał prof. Wojciech Polak. Rozprawiał on na temat kłamstwa i jego niszczącego wpływu na demokrację we współczesnym świecie. Natomiast o problemie nadużywania prawdy i uczciwości w marketingu politycznym, w szczególności w kampaniach wyborczych, rozprawiał prof. Marek Jeziński. Z kolei dr Sławomir Drelich analizie poddał populizm polityczny, który posługuje się wartościami prawdy, uczciwości, reprezentowanymi przez naród/lud. Następnie do dyskusji włączyli się: publicysta Paweł Wroński, prof. Andrzej Zybertowicz, ks. dr Tomasz Dutkiewicz. Głos zabrali również prof. Włodzimierz Tyburski, prof. Jan Kopcewicz, ks. biskup Andrzej Suski, prof. Andrzej Jamiołkowski, a także ks. Jerzy Molin. Osią podejmowanych rozważań była kwestia oceny intencji polityków. Zastanawiano się, czy politycy kłamią? Czy to, co mówią, obiecują chcą na pewno realizować? Dominującą wykładnią XIX Toruńskich Spotkań Colloquia Torunensia uczyniono ósme przekazanie „Nie mów fałszywego świadectwa przeciw bliźniemu swemu".

Sobotnie obrady w toruńskim Dworze Artusa otworzył JM rektor Uniwersytetu Mikołaja Kopernika w Toruniu, prof. Andrzej Tretyn. Powitał przybyłych gości, w tym szczególnie reprezentantów władz miejskich, samorządowych, powiatowych, wojewódzkich oraz przedstawicieli duchowieństwa, a także pracowników naukowych, studentów i wszystkich zgromadzonych. Następnie powitał i przedstawił bohaterów tego wydarzenia, czyli prof. Andrzeja Szahaja, filozofa, dziekana Wydziału Humanistycznego UMK, ks. prof. Alfreda Wierzbickiego z Katolickiego Uniwersytetu Lubelskiego, Pawła Wrońskiego, publicystę Gazety Wyborczej, prof. Andrzeja Zybertowicza, socjologa z UMK oraz moderatora tego panelu, prof. Ryszarda Wiśniewskiego, etyka z UMK. Rektor, prof. A. Tretyn, na początku omówił tematykę tegorocznej debaty, a także docenił ważność poruszanych podczas spotkań zagadnień. Zaznaczył, że nie po raz pierwszy temat dyskusji koncentruje się wokół problematyki prawdy i uczciwości. Podkreślił, że te wartości mają także szczególne znaczenie w środowisku ludzi nauki. W tym kontekście wspomniał o przyjętej przez Uniwersytet Mikołaj Kopernika dewizie, która nakazuje Veritas in omnibus quaerenda est („We wszystkim szukać prawdy").

Następnie głos zabrał prof. Ryszard Wiśniewski, który przybliżył wyniki piątkowych obrad. Zaznaczył, że mimo wielu dyskusji nadal występuje brak zadowalającej definicji prawdy, która obok uczciwości stanowi podstawową normę życia ludzkiego, a jednocześnie punkt odniesienia tegorocznych rozważań. Jego zdaniem, spór o prawdę jest odwieczny. Prawda funkcjonuje zarówno w sferze publicznej, między innymi w postaci różnych ideologii, oraz w sferze prywatnej, a także następuje proces wzajemnego przenika- 
nia się tych wartości. Podkreślił jednak, że celem podejmowanych rozważań nie jest spór, ale dyskusja na temat znaczenia prawdy i uczciwości w sferze publicznej, z perspektywy filozoficznej, socjologicznej i politycznej. Prof. R. Wiśniewski wskazał również na cztery zasadnicze obszary podejmowanych debat: 1) analiza pojęć: prawda i uczciwość; 2) rozumienie normy „nie mów fałszywego świadectwa przeciw bliźniemu swemu”; 3) anatomia fałszu politycznego i prawdy, szczególnie koncentrując się na negatywnym znaczeniu; 4) podstawowe zasady etyki w życiu publicznym: czy kłamstwo/ przeinaczenia są usprawiedliwialne?

Jako pierwszy zdefiniowania prawdy i uczciwości z perspektywy filozoficznej podjął się ks. prof. Alfred Wierzbicki. Na początku określił prawdę i uczciwość. Zaznaczył, że prawda jest wartością poznawczą, ponieważ stanowi rezultat naszego poznania (prawdziwy lub fałszywy), natomiast uczciwość należy do kategorii moralnej, która łączy się z prawdą w postaci stosunku człowieka do prawdy, a także wpływa na jego obraz świata. Zwrócił również uwagę, że prawda stanowi wynik doświadczenia zbiorowego i można ją odkrywać przy pomocy różnych narzędzi. Prof. A. Wierzbicki wskazał na trzy zasadnicze instytucje - akademię, parlament i media, z których każda powinna koncentrować się na poszukiwaniu prawdy. Jego zdaniem, kiedy jednostka ludzka nie zna prawdy, to powinna dążyć do jej poznania. Z kolei uczciwość, w opinii tego filozofa, dotyczy granic wiedzy człowieka. Odwołał się on do tradycji greckiej i przywołał dewizę Sokratesa - „wiem, że nic nie wiem", a także wskazał akademię platońską jako miejsce poszukiwania uczciwości i prawdy. Następnie prof. Wierzbicki przybliżył problematykę wymiarów uczciwości. Pierwszy z nich dotyczy granic prawdy, drugi zdolności słuchania i przyjmowania prawdy. Podkreślił, że należy poznawać prawdę, ale także kochać, respektować każdą prawdę i od każdego, tak jak to czynił św. Tomasz z Akwinu, który mawiał ,nie patrz kto mówi, ale co mówi”. Dlatego uznał, że obiektywność prawdy jest aleteiczna - następuje odsłanianie prawdy, która wspólnie przekonuje. Jako trzeci wymiar uczciwości wymienił uznanie, a także wiązanie się z prawdą. Zagadnienie to przedstawił w odniesieniu do sumienia, które stanowi wyraz dogłębnego ludzkiego przekonania, kiedy prawda przechodzi w powinność. Na koniec wskazał na potrzebę głębokiego namysłu nad prawdą.

W tym kontekście stanowisko filozoficzne zaprezentował również prof. Andrzej Szahaj. Na początku wskazał na wiele trudności związanych z definiowaniem i rozumieniem prawdy, między innymi z powodu istnienia różnych koncepcji tej wartości. Zaznaczył, że w kontekście życia społecznego, w sferze komunikowania się, ludzie częściej posługują się kategorią prawdomówności niż prawdy, ponieważ chcą przedstawiać to, co naprawdę myślą. Prof. A. Szahaj podkreślił, iż nie wszędzie norma prawdomówności jest re- 
spektowana. Dla zobrazowania podał przykład kultur zamieszkujących wyspy malezyjskie, gdzie mieszkańcy posługują się nieprawdą. Jednak należy dokonać rozróżnienia normy i standardu od życia codziennego. W swojej wypowiedzi poruszył on również zagadnienie dotyczące sporu z prawdą w sferze publicznej. Wskazał pewne niebezpieczeństwa wynikające z uznawania prawdy przez duże P jedynie przez wybrane grupy społeczne. Jego zdaniem, kluczowym kryterium prawdy jest wolność, a nieodzownym warunkiem poznania prawdy jest spotkanie oparte na swobodnej dyskusji o prawdzie. Stwierdził, że trzeba zatroszczyć się o debatę, komunikację, a ich rezultatem będzie prawda.

Z kolei socjolog, prof. Andrzej Zybertowicz, swoje rozważania rozpoczął od zdefiniowania kłamstwa. Wskazał, że kłamstwo jest skuteczne w kontaktach międzyludzkich, w kampaniach czy marketingu i porównał je do pasożyta $\mathrm{w}$ organizmie. Zastanawiał się nad granicami skuteczności kłamstwa, a także nad granicami nieuczciwości. Jego zdaniem sentymentalne spojrzenie na wartość prawdy i uczciwości wymusza instytucjonalne rozwiązania, które będą chronić przestrzeń prawdy i uczciwości. Stwierdził, że prawda zwycięża nie bez oręża, prawda bezorężna staje się zabytkiem, a następnie rozważał, co może być orężem prawdy. Wśród tych instytucjonalnych wymienił wolne media czy uniwersytet. Dalej prof. A. Zybertowicz zastanawiał się, czy ostatecznym orężem prawdy nie może być odwaga obrony wolności tych, którzy w prawdę wierzą. Jednak zaznaczył, że strażnikiem i orężem prawdy jest wiara, niedająca się empirycznie zbadać i wytłumaczyć. W jego opinii najważniejsza staje się wiara, że przekaz zawarty w dekalogu wyraża głęboki kod kulturowy, bez którego nie zostanie ocalona prawda i uczciwość.

Głos w tej dyskusji zabrał także przedstawiciel świata mediów - Paweł Wroński. Podejmowane rozważania rozpoczął od zdefiniowania prawdy poprzez podanie przykładu z własnej pracy zawodowej. Odwołał się również do współczesnej sytuacji, kiedy dziennikarze, czasami nawet pod przymusem, postępują przeciw ósmemu przykazaniu. Podkreślił, że o prawdziwości świadczy informacja oraz opinia, na której opiera się prezentowana wiedza, która powinna stanowić niepodważalny i weryfikowalny fakt. Dodatkowo wskazał, iż w pracy dziennikarza prawda musi być również atrakcyjna, przedstawiona w interesujący sposób oraz w określonych konwencjach stylistycznych.

W kolejnej części sobotnich obrad analizie poddano normę 8 przykazania „nie mów fałszywego świadectwa przeciw bliźniemu swemu”. Jako pierwszy wyjaśnienia tego zagadnienia podjął się prof. Alfred Wierzbicki. W tym celu odwołał się do tradycji judeochrześcijańskiej. Na tej podstawie wyjaśnił kim jest „bliźni”. Ostatecznie podkreślił, że bliźnim jest każdy człowiek niezależnie od religii, narodowości czy rasy. W swojej wypowiedzi 
nawiązał także do ewangelii, która nakazuje zobaczyć bliźniego, a z drugiej otoczyć go troską i szacunkiem. Prof. A. Wierzbicki podkreślił, że pomiędzy prawem do prawdy a prawem do życia zawiera się wszystko, co możemy dać drugiemu człowiekowi.

Z kolei prof. Andrzej Szahaj nawiązał do wcześniejszego swojego stwierdzenia, że drogą do prawdy jest dyskusja, dialog, którym należy objąć wszystkich. Jednak nie każdy może w niej uczestniczyć. W tym kontekście omówił zagadanie związane z wykluczaniem pewnych kultur/grup społecznych z debaty publicznej. Zauważył, że zarówno w wymiarze narodowym, jak i międzynarodowym debaty/dyskusje wykluczają sporą grupę ludzi. Nie mogą oni wypowiadać swojej prawdy oraz nie są traktowani jako równorzędni partnerzy rozmowy. Jako przykład podał udział społeczeństwa polskiego w wyborach, gdzie niewielu ludzi uczestniczy, ponieważ większość nie widzi szans i możliwości, żeby zaistnieć w tej debacie. Jako kolejny sposób wykluczenia podał wojnę. Wówczas następuje hierarchizacja pewnych wartości i nie wszyscy ludzie są włączani, ponieważ obowiązuje przywiązanie do własnej kultury. Na koniec stwierdził, że bez względu na to, co jednostki ludzkie mówią, w praktyce postępują inaczej.

Publicysta Paweł Wroński w swojej wypowiedzi wskazał na ósme przykazanie jako kluczowe zagadnienie we współczesnym świecie oraz ukazał jego znaczenie zarówno w okresie wojny, jak i w czasie pokoju. Podkreślił, że okłamywanie staje się elementem walki politycznej. Następnie odwołał się do własnej profesji, pokazując rolę mediów współcześnie, jak i dawnej. Stwierdził, że od pewnego czasu media są artylerią w sporze, a nie arbitrem. Nie zajmują one jakiegokolwiek stanowiska, ponieważ wzajemnie się nienawidzą, natomiast w przeszłości służyły społeczności.

$Z$ kolei prof. A. Zybertowicz nie udzielił odpowiedzi na zadane przez prof. R. Wiśniewskiego pytanie. Zmienił dotychczasową konwencję wypowiedzi z monologu na dialog. Otóż zadał pytanie Pawłowi Wrońskiemu: jaka ideologia wyłania się z ideologii krzyża zamieszczanej na łamach Gazety Wyborczej? Jakie lepsze wartości/tabu prezentuje ta gazeta? Prof. A. Zybertowicz dodał również, że niektóre projekty okładek Gazety Wyborczej stanowią atak na fundamenty cywilizacji chrześcijańskiej. Pytanie te zostało przeniesione do II części obrad.

Kolejny etap dyskusji ogniskował wokół anatomii fałszu: dlaczego my tacy jesteśmy? Jakie są społeczne uwarunkowania tego, że tacy jesteśmy? $\mathrm{W}$ podejmowanych rozważaniach uwzględniono także dopuszczalności, usprawiedliwialności tego rodzaju postaw: czy z praktycznego punktu wiedzenia można takie zachowanie etycznie usprawiedliwić?

Jako pierwszy w tej kwestii wypowiedział się prof. A. Szahaj, który osią swoich rozważań uczynił politykę, ponieważ zawiera ona wiele kłamstwa, 
niespełnionych obietnic i manipulacji. Wyjaśnił znaczenie kryterium opłacalności i skuteczności fałszu. Zwrócił uwagę, że pewne procesy demoralizacji, istniejące $\mathrm{w}$ polskiej polityce, są obecne w innych państwach. Zastanawiał się, czy polityka jest skazana na takie zachowania? Wskazał przykład osób, które starały się uprawiać uczciwą politykę: premiera Polski - Tadeusza Mazowieckiego czy prezydenta USA - Jimmy`ego Cartera, a także ukazał proces demoralizacji ludzi w systemie politycznym. Z drugiej strony prof. A. Szahaj zaprezentował kwestię dotyczącą nieuczciwości, kłamstwa w życiu gospodarczym. Uznał, że współcześnie mamy stan narodzin kapitalizmu „małego druku” czy „małych liter”, ponieważ to, co najważniejsze, jest zapisywane małymi literkami, żeby nikt tego nie przeczytał bądź tego nie zrozumiał. Przybliżył konsekwencje społeczne i moralne wynikające z ewolucji gospodarki kapitalistycznej. Podkreślił, że we współczesnym systemie etyka przegrywa $\mathrm{z}$ rynkiem, ponieważ wymusza ona na ludziach działania niemoralne, które stają się jedynym gwarantem ,jakiegoś” sukcesu gospodarczego. Jego zdaniem, sytuacja ta jest początkiem końca pewnej formy cywilizacji.

Głos w tej debacie zabrał następnie Paweł Wroński. Na początku przywołał własne doświadczenia związane z nieprawym zachowaniem ludzkim, a także wskazał na problem nieuczciwości i postępujący współcześnie deficyt zaufania społecznego. Przyczyn tego stanu doszukiwał się w procesie wychowania dzieci. Przywołał dwie osoby ze sceny politycznej końca XX wieku, to znaczy Tadeusza Mazowieckiego i Jana Olszewskiego, którzy postępowali według zasad moralnych, lecz byli politykami przegranymi. Następnie wyjaśnił zagadnienie dotyczące „wąskiej przestrzeni”, związanej z granicami manipulacji polityków oraz jej konsekwencje. P. Wroński ukazał również rolę dziennikarza w sporze między politycznym pragmatyzmem a politycznym idealizmem. Podkreślił, że dziennikarz nie może usprawiedliwiać postępowania polityka, lecz powinien od niego wymagać. Omówił także jedną z najgorszych form polityki, polegającą na budzeniu nieufności społecznej, czyli politykę symulacyjną, i wyjaśnił jej następstwa. Z nadzieją stwierdził, że od czasu do czasu pewne wartości moralne, to jest prawda, uczciwość w tej sferze triumfują i ,ja bym generalnie wolał być ich sojusznikiem".

Z kolei prof. Wierzbicki wskazał na niepokojącą sytuację walki o prawdę i zwycięstwo prawdy. Jednak zauważył, że ,prawda ucieka z obozu zwycięzców" (cyt. za Simone Weil). Zastanawiał się nad przyczynami tej sytuacji i wymienił trzy zasadnicze czynniki. Jako pierwszy powód wskazał władzę, ponieważ zmienia ona sposób patrzenia człowieka. Jego zdaniem, drugim elementem jest chciwość, szczególnie dostrzegalna w sferze gospodarczej. Podkreślił, że tylko wyrzuty sumienia mogą uratować człowieka we 
współczesnym świecie, przepełnionym dyskusją o polityce, a nie kulturą polityczna. Natomiast jako trzeci czynnik wymienił Kościół, który w ostatnim ćwierćwieczu utracił kapitał duchowy, moralny, a także zdolności komunikacyjne. Zaznaczył, że Kościół obecnie nie uczestniczy w forach dyskusyjnych, ponieważ jest podzielny na tle ideologicznym, teologicznym i najczęściej przyjmuje postawę defensywną. Wyraził jednak nadzieję na zmianę tej sytuacji, poprzez „więcej namysłu, aniżeli walki” (Paweł Włodkowic), a wówczas każda debata będzie swoistą okazją do wzajemnego uczenia się.

Ostatni w tej kwestii wypowiedział się prof. A. Zybertowicz. Początkowo skoncentrował się na omówieniu problematyki dotyczącej konkurencji i walki, która toczy się zarówno w życiu społecznym, jak i w nauce. Następnie poruszył zagadnienie dotyczące kapitalizmu, ze wskazaniem elementów złego kapitalizmu na przykładzie badań amerykańskich przeprowadzonych wśród studentów ekonomii, celem poznania ich skłonności do oszukiwania. $\mathrm{Na}$ tej podstawie stwierdził, że rozum empatyczny został wyparty przez rozum kalkulacyjny i mentalność kalkulacyjną, w której nie uwzględnia się zasad etyki. Uznał, iż kluczowe instytucje kapitalizmu postępują w sposób amoralny, lekceważąc wartość człowieka. Jako przykład podał wielkie banki, korporacje czy call center, gdzie stosuje się określone metody manipulacyjne. Prof. A. Zybertowicz szczególnie wiele miejsca poświęcił tej ostatniej instytucji, gdzie pracują głownie młodzi ludzie, którzy na początku swojej drogi zawodowej są wdrażani instytucjonalnie w manipulowanie, nawet pod groźbą utraty pracy. Ukazał konsekwencje związane z wykonywaniem tego typu obowiązków, ponieważ nawyki myślowe wyniesione z pracy mogą oni także zastosować w innych sytuacjach, zwłaszcza jeśli przynoszą pożądane efekty.

W kolejnej części sobotnich obrad nastąpiła wymiana opinii. Jako pierwszy głos zabrał Paweł Wroński, który ustosunkował się do pytania prof. A. Zybertowicza dotyczącego wartości, jakie proponuje „Gazeta Wyborcza” zamiast katolicyzmu. Początkowo podkreślił, że środowisko „Gazety Wyborczej" nie pochwala postaw nieetycznych. Wskazał na trudności związane ze zwalczaniem takich zachowań, które są obecne w środowisku pracy (między innymi w korporacjach i call center). Zaprezentował swoje stanowisko dotyczące wartości religijnych, w którym zaznaczył, że ludzie powinni kierować się wartościami zawartymi w dekalogu, między innymi nie powinni oszukiwać, powinni jeździć z dozwoloną szybkościa, powinni się zachowywać przyzwoicie itp. Jednak do tych wszystkich cnót dołączył tolerancję.

Następnie prof. A. Wierzbicki zabrał głos w sprawie okładek projektowanych przez różne pisma i przekazywane w ten sposób wartości. Z kolei prof. Szahaj zaznaczył, że należy na pewne zagadnienia spojrzeć szerzej, nie tyle z perspektywy wartości chrześcijańskich, lecz jako na spójny system 
wartości moralnych. Jego zdaniem, chrześcijaństwo przegrywa z obecnym amoralnym rynkiem kapitalistycznym, który jest obojętny na jakiekolwiek wartości. Wyjaśnił również logikę kontroli i zaistniałych zmian w systemie kapitalistycznym. Konkludował, że współcześnie ten system nie postępuje według zasad moralnych, lecz posługuje się tylko jedną ideą - ideą zysku za wszelką cenę.

W dalszej części obrad nastąiła dyskusja z uczestnikami tego spotkania. Jako pierwszy głos zabrał dr Janusz Czarnecki. Zagadnienia związana z prawdą i uczciwością ukazał z perspektywy medycznej. Zaznaczył, że zdrowie jest $w$ interesie całego państwa, społeczeństwa, a także poszczególnych jednostek. Przedstawił konsekwencje biologiczne wynikające z posługiwaniem się w życiu kłamstwem. Uznał, że prawda związana jest ze zdrowiem ludzkim. Następnie swoje stanowisko zaprezentował prof. Piotr Petrykowski - pedagog. Podkreślił, że prawda nie jest odkrywalna, lecz rzeczą ludzką jest dochodzić do prawdy, którą porównał do słońca. W tym kontekście przywołał przykład Jezusa z Nazaretu, proszącego o wodę samarytankę oraz przytoczył opowieść z Księgi Rodzaju. Z perspektywy prawnej stanowisko zaprezentował dr Michał Piwnicki. Zaznaczył, że prawda jest inaczej rozumiana i odbierana przez społeczeństwo, ludzi będących blisko pewnych zdarzeń. Zaproponował, aby prawda była odbierana na zasadzie faktu. Podkreślił, że etyczność powinna być skierowana w stronę mediów, ponieważ to one kreują obraz niejednokrotnie wyidealizowany, niekiedy nawet posługując się kłamstwem. Głos w tej dyskusji zabrał również prof. Wojciech Polak. Wyjaśnił on znaczenie kilku okładek pism polskich. Następnie poruszył kwestie związane z katastrofą smoleńską i późniejszą walką o krzyż, celem pokazania podłoża konfliktu dwóch równoprawnych obozów, gdzie jeden posiada władzę, a drugi nie zgadza się z tą władzą, ponieważ inaczej postrzegają pewne wydarzenia. Z kolei prof. Grażyna Halkiewicz-Sojak powołała się na słowa Kamila Cypriana Norwida: „Prawda się razem dochodzi i czeka”, celem uwypuklenia słowa „razem”, którego brakuje w podejmowanych dyskusjach, a jednocześnie stanowi podłoże wykluczenia wielu ludzi z debaty publicznej. W dalszej części wypowiedzi wyjaśniła ona także znaczenie pojęć prawda obiektywna i prawda subiektywna w nawiązaniu do współczesności oraz znaczenie uniwersalizmów (uniwersalizmu chrześcijańskiego i uniwersalizmu oświeceniowego) w debacie publicznej. Poruszyła również problem braku zaufania i wykluczenia wielu środowisk z dyskusji. Na zakończenie zwróciła uwagę na błąd, jaki Polska popełniła przy konstruowaniu państwa prawa, ponieważ przyjęte zostały wzory zewnętrzne, a wyparte doświadczenia historyczne. Jako ostatni w tej części obrad wypowiedział się prawnik, Mateusz Marzec. Stwierdził, że uczciwość i prawda opłacają się oraz wskazał niepokojące problemy życia społecz- 
nego: brak uczciwości i brak poczucia wspólnoty. Na koniec pojawiły się wypowiedzi podsumowujące ze strony panelistów, a prof. R. Wiśniewski podziękował wszystkim uczestnikom za obecność i zaznaczył, że podczas tegorocznej debaty „etos dialogu zwyciężył”.

Konkludując trzeba stwierdzić, że XIX Colloquia Torunensia stały się doskonałym sposobem interdyscyplinarnego spojrzenia i wymiany podglądów na temat prawdy i uczciwości, ze szczególnym uwzględnieniem tych wartości w debacie publicznej. Dyskusja ogniskowała wokół czterech zasadniczych zagadnień. $Z$ jednej strony przeanalizowano pojęcie prawdy i uczciwości, następnie wyjaśniono normę ósmego przykazania: „Nie mów fałszywego świadectwa przeciw bliźniemu swemu!”. Jednak niezwykle interesująca okazała się ta część debaty, która dotyczyła znaczenia zasad etyki w życiu publicznym. Szczególnie ważne były słowa na temat kłamstwa i nieuczciwego postępowania człowieka w różnych sferach jego działalności, między innymi politycznej, społecznej i gospodarczej. Dyskutowano nad konsekwencjami takiego zachowania, a także próbowano wskazać granice prawdy i uczciwości. Jednak problematyka tegorocznej debaty jest niezwykle rozległa i nadal nurtuje przedstawicieli różnych dyscyplin naukowych. Dlatego mimo pojawienia się wielu znaczących głosów w tej kwestii, zagadnienie pozostaje nadal otwarte i zawsze aktualne na dalsze rozważania, a przy tym niezwykle cenne w każdym aspekcie ludzkiego życia. 
